\title{
Brasiliano-age granitoids in the Sergipana Fold Belt, NE Brazil: the Coronel João Sá Pluton
}

\author{
I. McREATH*1 , J.M. LAFON†, I. DAVISON‡, J.M. CHAVES§ and H. CONCEIÇÃOף
}

*Departamento de Geologia Geral, Instituto de Geociências, USP, São Paulo, SP, Brazil †Laboratório de Geologia Isotópica, Centro de Geociências, UFPA, Belém, PA, Brazil $\ddagger$ Department of Geology, Royal Holloway College, University of London, Egham, Surrey, UK §Departamento de Ciências Exatas, UEFS, Feira de Santana, BA, Brazil ๆCurso de Pós Graduação em Geologia, Instituto de Geociências, UFBA, Salvador, BA, Brazil

\begin{abstract}
The Coronel João Sá pluton is a zoned Brasiliano-age, late- to post-tectonic intrusion in the Macururé schist domain of the Sergipana Foldbelt, Northeast Brazil. Biotite-hornblende granodiorite predominates, and flattened ultramafic to intermediate enclaves are present. Igneous orientations are present but fabrics produced by strong solid-state flattening are absent. $\mathrm{Rb}$-Sr whole rock isochrons including enclaves and their host rocks yielded a probable intrusion age of $614 \mathrm{Ma}$ which dates the waning phase of the dominant deformation which produced the F2 foliation of the Sergipana belt and is close to ages reported for late tectonic granites in other Brasiliano domains of Northeast Brazil. More radiogenic $\mathrm{Sr}$ $\left(\mathrm{I}_{\mathrm{Sr}(614)}=0.71008 \pm 52\right)$ is present in some felsic rocks, while less radiogenic $\operatorname{Sr}\left(\mathrm{I}_{\mathrm{Sr}(614)}=0.70814 \pm 18\right)$ is mainly found in the more mafic core of the main body. $\mathrm{Sr}$ isotopic equilibrium between most enclaves and their host rocks was attained. Textural evidence, especially in the enclaves, shows that magma mixing occurred, but late biotite formation in the enclaves caused modifications of their chemical compositions. The geological, petrographical and isotopic evidence shows that the pluton was probably fed by a complex feeder system into the crust under extensional conditions. Variable upper crustal contamination was probably responsible for the isotopic heterogeneity of Sr. (C) 1998 Elsevier Science Ltd. All rights reserved

Resumo - O pluton de Coronel João Sá é uma intrusão zonada, tardi a pós-tectônica, de idade brasiliana, no dominio dos xistos Macururé dentro da Faixa Sergipana no Nordeste do Brasil. Granodiorito a hornblenda e biotita predomina e encraves achatados, ultramáficos a intermediários estão presentes. Encontra-se orientação de origem magmática, porém tramas devido a achatamento forte no estado sólido estão ausentes. Isócronas $\mathrm{Rb}$-Sr em rocha total, incluindo-se tanto os encraves como os granodioritos, fornecem uma provável idade de intrusão de $614 \mathrm{Ma}$, que data a fase decadente da deformação principal que deu origem à foliação F2 na Faixa Sergipana, e aproxima-se das idades obtidas para granitóides tardi-tectônicos em outros domínios brasilianos do Nordeste brasileiro. $\mathrm{Sr}$ mais radiogênico $\left(\mathrm{I}_{\mathrm{Sr}_{\mathbf{r}(614)}}=0.71008 \pm 52\right)$ está presente em algumas das rochas mais félsicas, enquanto $\mathrm{Sr}$ menos radiogênico $\left(\mathrm{I}_{\mathrm{Sr}(614)}=0.70814 \pm 18\right)$ está presente principalmente na parte central, a mais máfica do corpo. Alcançou-se equilibrio isotópico entre encraves e suas rochas hospedeiras. Evidência textural, especialmente nos encraves, demonstra que mistura de magmas foi um processo petrogenético importante. A formação tardia de biotita nos encraves modificou suas composições químicas. As evidências geológicas, petrográficas e isotópicas sugerem que o pluton alimentou-se através de um sistema complexo quando de sua intrusão na crosta sob codições de extensão. É provável que a heterogeneidade isotópica de Sr se deva a processos de contaminação crustal diferentes em cada parte do sistema de alimentação. (C) 1998 Elsevier Science Ltd. All rights reserved
\end{abstract}

\section{INTRODUCTION}

The Coronel João Sá (CJS) pluton is an example of the abundant Brasiliano-age, late- to post-tectonic granitoid intrusions which occupy about $20-25 \%$ of the western part of the Macurure schist domain of the Sergipana Fold Belt of NE Brazil (Fig. 1). The age of the body is important for dating the main collision event in this region. An attempt to date the intrusion by the $\mathrm{Rb}-\mathrm{Sr}$ whole-rock isochron method (Santos et al. 1988) yielded an unexpectedly old apparent age of about $840 \mathrm{Ma}$. The presence of abundant fine to medium-grained, mafic to intermediate enclaves led Guimarães and Silva Filho (1993) to propose that the rocks of the pluton were generated by magma mixing. In such cases, the union of mafic and felsic rocks from isotopically different sources on the same isochron may lead to spurious apparent ages, a wellknown phenomenon already recognized in dating some types of Brasiliano-age granitoids from NE Brazil
(Macedo et al. 1993), for which a magma mixing origin is often inferred (Mariano and Sial, 1990; Sial et al. 1992; Neves and Vauchez, 1995). We present an account of the geology and petrology of the CJS pluton, together with new geochemical data, including Rb-Sr isotopic compositions, on enclaves and host rocks. A new, much younger age for the pluton is obtained. The hypothesis of magma mixing is examined from textural and geochemical viewpoints.

\section{The Sergipana fold belt}

This fold belt forms the southeastern limit of the Borborema Province, and is partially overthrust onto the northeastern border of the São Francisco Craton (Fig. 1 (inset); Almeida et al. 1981; Jardim de Sá et al. 1986; Campos Neto and Brito Neves, 1987). Davison and Santos (1989) discussed the structural evolution of the belt, and 


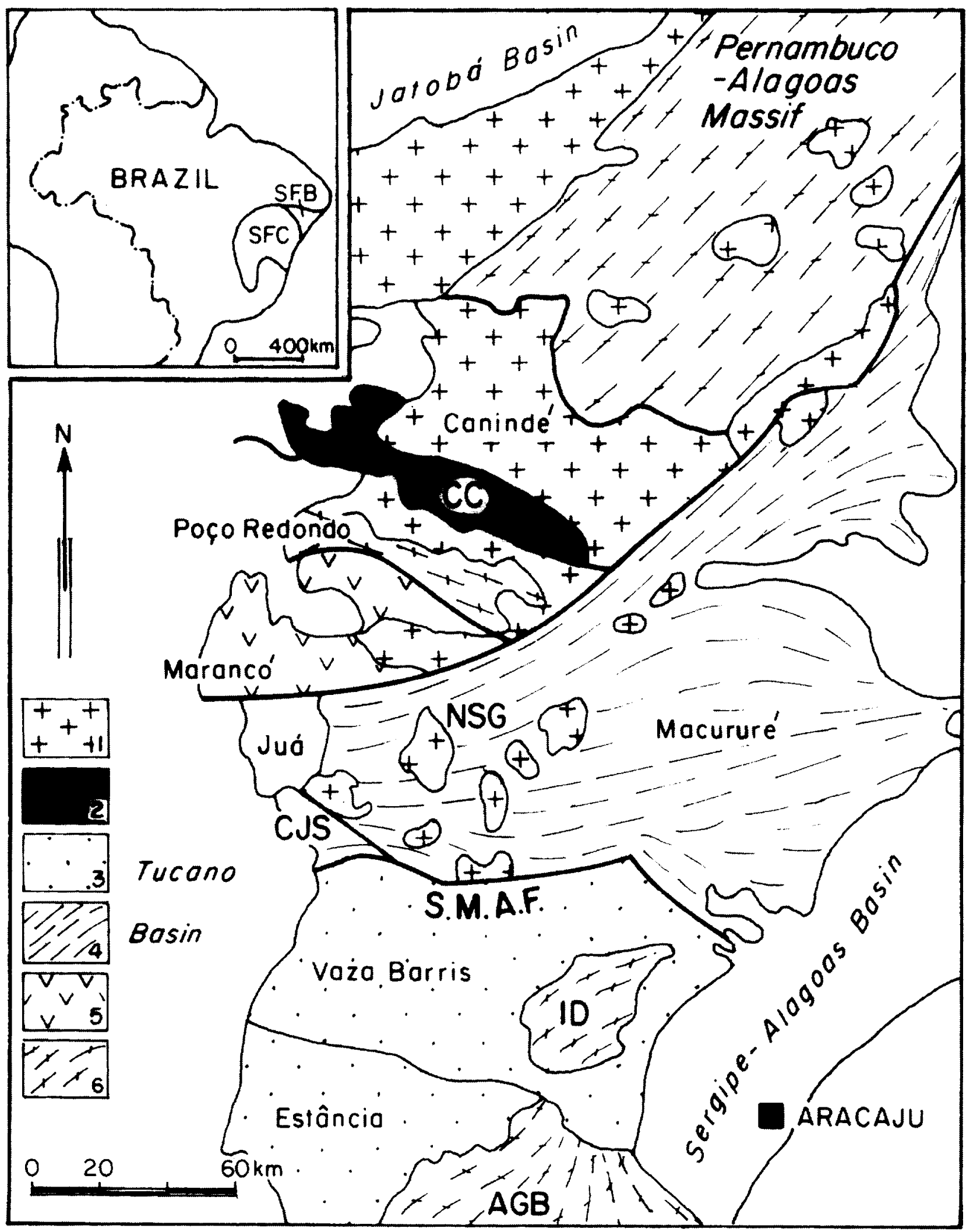

Fig. 1. Inset: Localization of the São Francisco craton and the Sergipana fold belt. Main map: the Sergipana fold belt, east of the Phanerozoic Jatobá-Tucano-Reconcavo Basin. 1) granites: CJS - Coronel João Sá, NSG - Nossa Senhora da Glória; 2) Canindé domain including the Canindé igneous complex (CC); 3) low grade, predominantly detritic metasediments, no outcropping granite intrusions; 4) Macururé schists; 5) Marancó metavolcano-plutono-sedimentary sequence; 6) high grade metamorphic terranes, including the Atlantic granulite belt (AGB), the Itabaiana dome (ID), the Poço Redondo domain and the Pernambuco - Alagoas massif; SMAF -- São Miguel do Aleixo fault; Juá -.. Juá graben; Sergipe - Alagoas basin: Cenozoic sediments. Adapted from Davison and Santos (1989). 
showed that it is composed of a number of lithological domains separated by shear or thrust zones. We adopt their model in this article.

The early stages of igneous activity and sedimentation in the Sergipana belt may have occurred in an ensialic environment (Davison and Santos, 1989; Oliveira and Tarney, 1990), while later evolution from a subductionrelated (e.g. Campos Neto and Brito Neves, 1987) to a continental collision environment (Guimarães and Silva Filho, 1994) has been proposed. Within the belt (Fig. 1, main map) there are: (1) a northwards shallow-dipping seismic discontinuity (Santos et al., 1988); (2) an increase in overall metamorphic grade from very low-grade metamorphism in the Estância Group in the south to anatectic grade in the Poço Redondo domain and the Pernambuco-Alagoas massif in the north; and (3) a zonation of granitoid types from predominately I-type in the southernmost occurrences to dominantly S-type or shoshonitic in the northernmost occurrences (Guimarães and Silva Filho, 1993, 1994). The CJS pluton represents a granitoid type which is common in the Macururé schist domain of metagraywackes and minor metavolcanic rocks in amphibolite facies in the southern part of the belt.

The absolute chronology of igneous events is unknown. Early igneous rocks form part of the supracrustal packets of the Miaba-Vaza Barris domain which contains rare dacites, and the Marancó domain, with abundant metarhyolites and metadacites, and subordinate orthoamphibolites, together with two serpentinite bodies (Santos et al., 1988). The Canindé Complex is composed of a volcano-sedimentary association with ultramafic, mafic and felsic components, intruded by gabbros (Davison and Santos, 1989; Oliveira and Tarney, 1990). A metarhyolite from the volcanic association yielded an age in the range 740-700 Ma (Van Schmus et al., 1995).

Davison and Santos (1989) described the deformation history of the Macururé domain. Recumbent $D_{1}$ folds are tight to isoclinal with southwestwards vergence. The axial plane cleavage contains biotite and garnet developed under amphibolite facies. The $\mathrm{D}_{2}$ deformation was responsible for the major structural trend in the domain. Axial planes dip $30^{\circ} \mathrm{NE}$ and fold axes have a southwestward vergence and a $135-150^{\circ}$ strike. These folds determine the present-day outcrop pattern of NW-SE trending ridges of more resistant quartzites. An axial plane cleavage defined by biotite developed in the fold hinges, indicating that the rocks were buried at significant depths $(>15 \mathrm{~km})$ when the deformation occurred. The $\mathrm{S}_{2}$ foliation traces are cut by or are deflected around the margins of the CJS pluton. Sinistral shear affected the $S_{2}$ foliation along the bifurcated São Miguel de Aleixo fault south of the CJS pluton (SMAF: Fig. 1), which was during its early evolution a major transpressional shear zone. The northern ramification of this fault forms part of the contact zone in the western part of the CJS pluton (Fig. 2), but no shearing is observed in the granite which therefore post-dates the latest movement along the fault. The $\mathrm{D}_{3}$ phase affected the NE portion of the Macururé domain shown in Figure 1 and was not important near the CJS pluton.

Granitoids attributed to the later ( $\sim 600 \mathrm{Ma})$ Brasiliano event include a syntectonic generation relative to the $F_{2}$ event, represented by the Serra Negra type composed of quartz-monzonitic augen gneisses and biotite-hornblende granodioritic gneisses (Santos et al, , 1988) to which mixed shoshonitic and alkaline affinities have been attributed. The major occurrence of these rocks is along the shear zone separating the Marancó and Poço Redondo domains (Fig. 1). Apart from the CJS type, the late to post-tectonic generation includes the transalkaline Sítios Novos type, found essentially in the Poço Redondo domain, while the post-tectonic generation includes saturated alkaline plutons close to the contact of the Sergipana belt with the Pernambuco-Alagoas massif (Santos and Souza, 1988).

\section{THE CORONEL JOĀO SÁ PLUTON}

The CJS pluton is the main subject of this study, but we will also briefly refer to the Nossa Senhora do Glória (NSG) pluton, about $30 \mathrm{~km}$ ENE of CJS (Fig. 1), part of which is petrographically very similar.

The CJS pluton has two parts (Fig. 2), both composed of medium to coarse-grained rocks which are mainly granodiorites using Streckeisen's (1976) modal classification. Plagioclase sometimes has more calcic cores (An>40), and is often complexly zoned with compositions mainly in the range An 28-35. The alkali feldspar is perthitic microcline. The main variety minerals are biotite and hornblende, but many rocks also contain some augite mantled by amphibole. Accessory minerals include anhedral to euhedral titanite, short prismatic apatite, allanite with epidote rims, magmatic epidote and zircon. An important feature of the accessory mineral assemblage is the scarcity or absence of Fe-Ti oxide minerals (Table 1).

The larger, southwestern body is zoned, with a small, nearly central core (IIICp) in which patches of gabbros or diorites and more mafic granodiorites with plagioclase and hornblende phenocrysts are accompanied by abundant, flattened or cigar-shaped enclaves with $\mathrm{cm}$ to $\mathrm{dm}$ major axes and $\mathrm{cm}$ minor axes. Continuous undeformed igneous banding over a few $m$ occurs in some outcrops, while discontinuous mafic schlieren are present in others. The latter could be very stretched enclaves or disrupted cumulate layers. Surrounding this core, the asymmetrical domain IIIC has less abundant enclaves, and the granitoids usually lack plagioclase phenocrysts.

Domain I forms the eastern extremity and contains two sub-domains, IS and IN (see later), both composed of biotite granodiorites with very little or no clinopyroxene or hornblende (Table 1). This domain has well-oriented crystal plastic strain fabrics (Hutton, 1988) which are most strongly developed at the contacts. Enclaves are not abundant. 


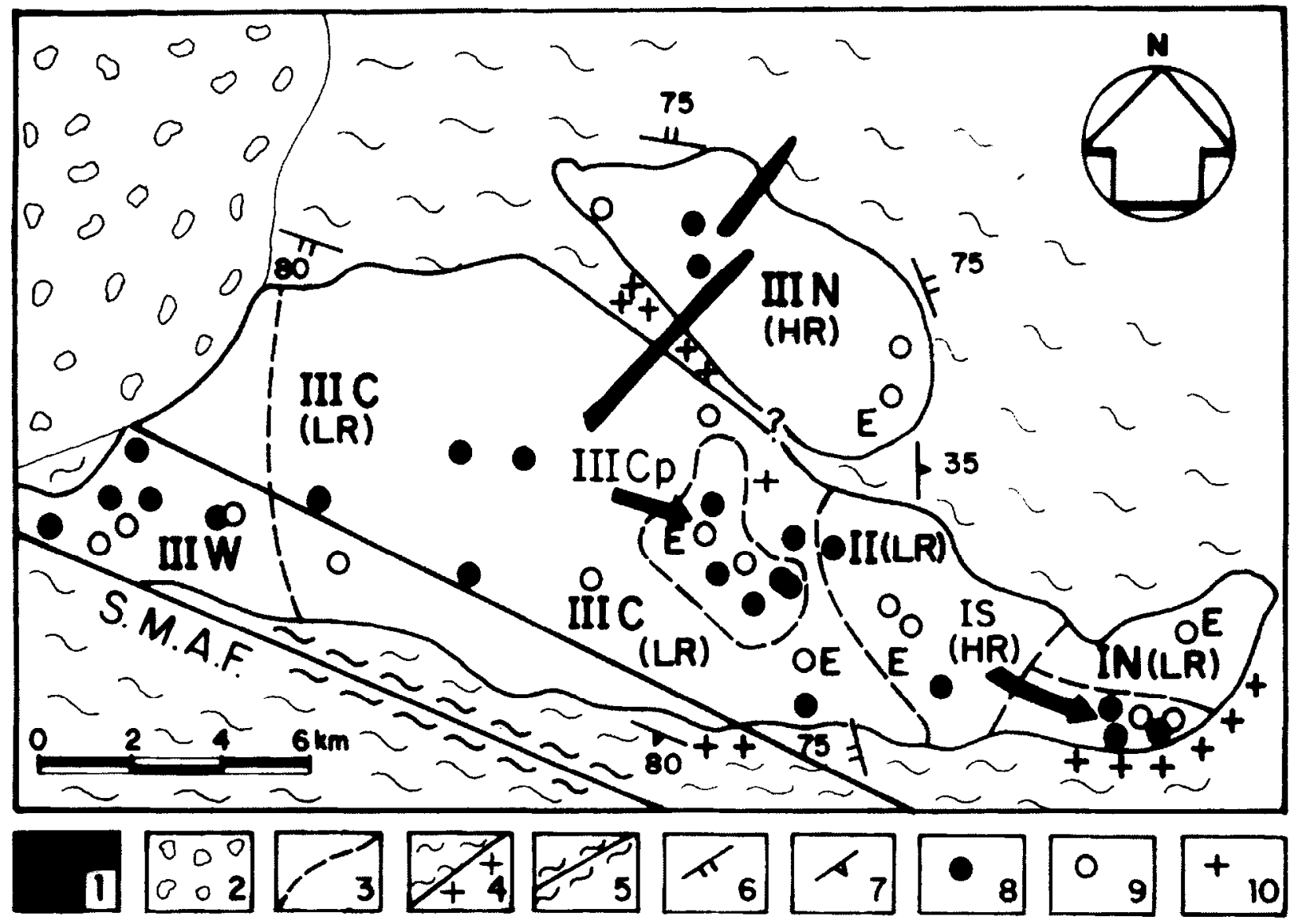

Fig. 2. The Coronel João Sá pluton: 1) late diabases; 2) Juá Conglomerate (Silurian-Devonian); 3) solid line, contact with country rocks; broken line, approximate domain boundaries in the CJS pluton; 4) (a) Macururé schists (b) contact aureole; 5) SMAF: São Miguel do Aleixo fault; 6) atitude of F2 foliation; 7) strike and dip of mylonitic foliation; 8) sample point, chemical analyses; 9) sample point, chemical and Sr-isotopic analyses; 10) Coronel João Sá village. E=enclave locality. Domains, see text. Adapted from Chaves (1991).

Table 1. Modal analyses of rocks from CJS pluton from Chaves (1991)

\begin{tabular}{|c|c|c|c|c|c|c|c|}
\hline Domain & $\stackrel{1}{\text { IS }}$ & $\begin{array}{l}2 \\
\text { II range }\end{array}$ & IIC range & $\begin{array}{c}4 \\
\text { IIIC }\end{array}$ & $\stackrel{5}{I I I C p}$ & IIICp range & $\begin{array}{c}7 \\
\text { I.IIIW \& IIIN } \\
\text { range }\end{array}$ \\
\hline Quartz & 28.3 & $20-25$ & 20.25 & 20.3 & $2 ! .4$ & $20-25$ & $25-30$ \\
\hline K-felds. & 18.9 & $10 \cdots 20$ & 1020 & 7.8 & 16.7 & 520 & $15-20$ \\
\hline Plag. & 38.9 & 3045 & $30-45$ & 50.9 & 36.2 & $30 \cdots 50$ & $35-40$ \\
\hline Clinopyx. & 0.0 & $\operatorname{tr}-3$ & 13 & 0.5 & 1.2 & $1-3$ & tr. \\
\hline Biot. & 5.4 & 10.20 & $10-20$ & 21.2 & 11.3 & $10-20$ & $5-20$ \\
\hline Hornb. & 2.4 & 15 & 15 & 4.6 & 44 & $5-10$ & $1-5$ \\
\hline Epidote & 2.7 & $\mathrm{acc}$ & acc. & ir. & 5.0 & acc: & acc. \\
\hline Titanite & 1.2 & acc. & acc. & 1.5 & 1.8 & acc. & acc. \\
\hline Apatite & 0.7 & acc. & acc. & 0.5 & 0.5 & acc. & acc. \\
\hline Zircon & 0.7 & acc. & dec & 0.4 & 0.4 & acc. & acc. \\
\hline Opaques & 0.0 & acc. & $\mathrm{dec}$ & is. & tr. & acc. & acc. \\
\hline Sericite & 0.6 & acc. & acc. & 2.3 & 1.1 & acc. & acc. \\
\hline Chlorite & 0.2 & acc. & acc. & ir. & tr & acc. & acc. \\
\hline Total & 100.0 & & & 100.0 & 100.0 & & \\
\hline
\end{tabular}

Slightly deformed granite and aplite apophyses were injected into the host pelitic schists, and are more frequent near domain IS. Narrow veins cross-cutting the aplites were slightly folded.

Domain II occurs between domains I and IIIC. The biotite-hornblende granodiorites of this domain lack the conspicuous hornblende phenocrysts which characterize domain IIIC. Enclaves are more abundant in domain II than in domain I, but are less abundant than in domain III.

At the western extremity of the main body, biotitegranodiorites of domain IIIW are more felsic and contain only traces of hornblende or clinopyroxene (Table 1). Enclaves are not abundant. Aplites are present at the contact. In contrast to domain I, the rocks of domain 
IIIW do not have strong crystal plastic strain fabrics, and the aplites are practically undeformed.

The northwestern satellite body (domain IIIN) seems to be separated from the main body by a septum of schists. It is composed of felsic biotite-hornblende granodiorites, very similar to those of domains I and IIIW (Table 1). Slightly porphyritic aplites cut the pluton-host rock contacts. Enclaves are not abundant.

The only continuous mafic bodies associated with the CJS pluton are NE-SW trending dykes which are also found in other parts of the fold belt. Slightly metamorphosed diabases from the Marancó domain were dated by the K-Ar method at $222 \mathrm{Ma}$ (Santos et al., 1988), and are therefore not genetically related to the CJS pluton.

Thermal metamorphism with growth of garnet and staurolite porhyroblasts affected various parts of the contact zone in the Macururé schists.

The presence of magmatic epidote may indicate that the initial crystallization of the granodiorite magmas started at pressures between $\sim 600$ and $\sim 800 \mathrm{MPa}$ (Zen and Hammarstrom, 1984; Schmidt, 1992). The metamorphic assemblages in the metagraywackes yield poorly-constrained pressure estimates between $\sim 150$ and $\sim 550 \mathrm{MPa}$, suggesting a maximum depth of intrusion of approximately $20 \mathrm{~km}$. Silva Filho and Guimarães (1994) obtained a mean value of $\mathrm{Al}_{\text {tot }}=1.81$ in hornblendes from the rocks of the CJS intrusion. Al-in-hornblende geobarometers yield pressures of crystallization of hornblendes between $420 \pm 50 \mathrm{MPa}$ (Johnson and Rutherford, 1989) and $550 \pm 60 \mathrm{MPa}$ (Schmidt, 1992).

\section{The enclaves}

Brief descriptions of some of the enclave types have already been given by Chaves (1991); Guimarães and Silva Filho (1993). Our detailed study is still in progress, and we include here only salient features. All samples have major axes between $\sim 10$ and $\sim 20 \mathrm{~cm}$. Shapes are commonly flattened disks. At each point the enclaves display compositional heterogeneity, but the local variation is usually not as large as the total variation observed in the pluton. The studied samples were chosen as representing the dominant enclave type at each outcrop. The more mafic enclaves are present in the more mafic parts of the pluton, and usually have less radiogenic $\mathrm{Sr}$ (LRG). The more felsic enclaves accompany the more felsic granodiorites, and have more radiogenic $\mathrm{Sr}(\mathrm{HRG}$; Fig. 3; see later). In some cases, host granites were collected at least $20 \mathrm{~cm}$ but less than $5 \mathrm{~m}$ from the analysed enclaves, forming enclave-host rock pairs.

The mafic enclaves usually contain acicular to fibrous apatite, indicating that the enclaves passed through a magmatic stage (Wyllie et al. 1962). An early anhydrous mineral assemblage is composed of plagioclase (An 50-40) and augite. The latter is substituted by colourless or green amphibole. Inclusions of K-feldspar and quartz "eyes" with mafic mineral borders demonstrate that magma mixing occurred (Hibbard, 1991; Vernon, 1990, 1991). The enclaves differ from many common mafic microgranular enclaves (Didier and Barbarin, 1991) as they lack chilled margins, but have rinds of brown biotite. Biotite is especially abundant in the mafic enclaves, where it substitutes clinopyroxene and amphibole. It also occurs

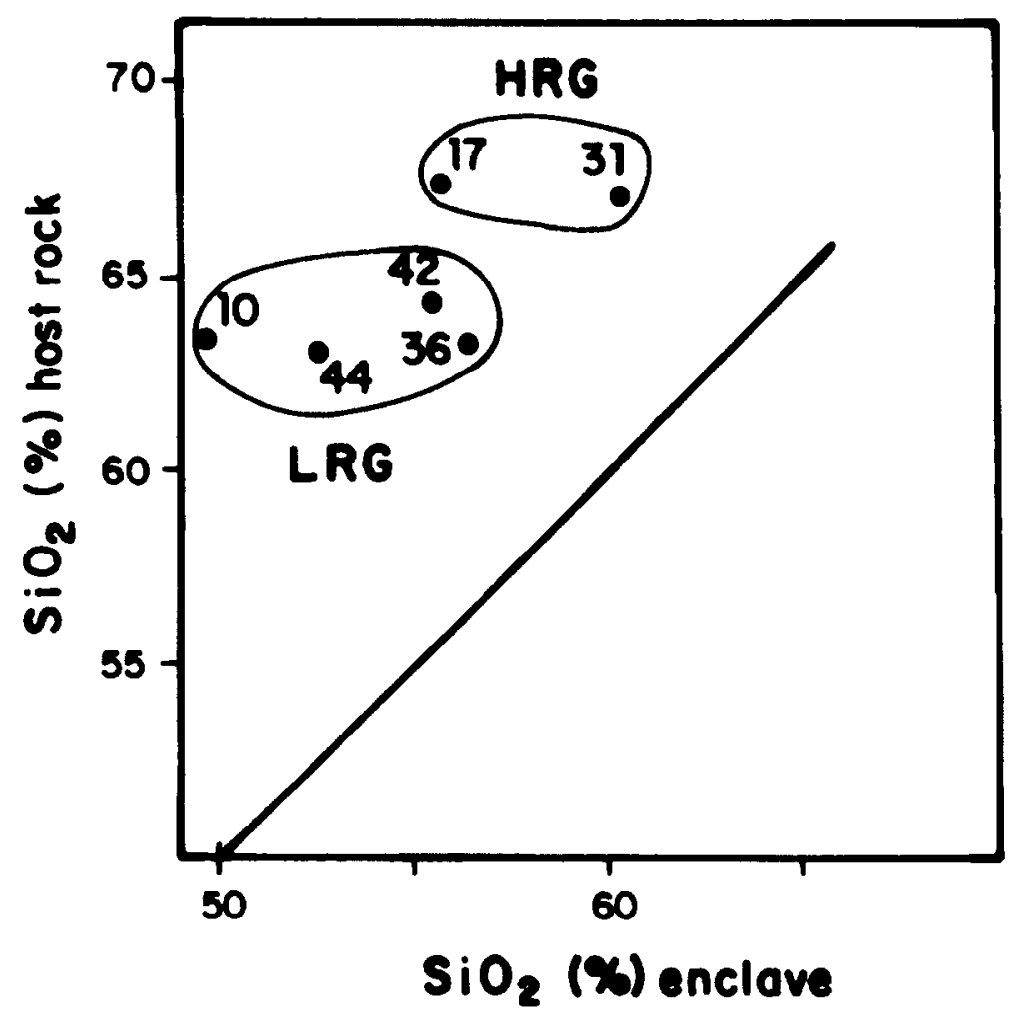

Fig. 3. Relationship between $\mathrm{SiO} 2$ in enclaves and in host rocks. $\mathrm{HRG}=$ high $\mathbf{l}_{\mathrm{Sr}(614)}$ granitoids, $\mathrm{LRG}=$ low $\mathbf{l}_{\mathrm{Sr}(614)}$ granitoids (see text). Samples, see Table 3. 
as individual crystals, without nuclei of other minerals, which were formed during flattening of the enclaves since in some cases the flakes have a moderate preferred orientation parallel to the plane of flattening, while in other cases the preferred orientation is only incipient. The origin of the biotite is not clear. In most cases, the surrounding granodiorite host rocks are not noticeably impoverished in mafic minerals close to the enclaves.

\section{Structures}

The $\mathrm{D}_{2}$ folding of the Macururé schists immediately around the CJS intrusion is of similar intensity to that elsewhere in the domain. Apophyses injected into the schists at the extreme SE tip (domain I) of the pluton are gently folded and boudinaged with pinch-and-swell structures up to $1 \mathrm{~m}$ wide, injected parallel to the $\left(\mathrm{S}_{1} / \mathrm{S}_{2}\right)$ foliation plane. Flattening was estimated at $20-30 \%$. This implies that at this stage the pluton was not injected under strong compression.

No strong internal deformation fabrics were developed in domains IIICp and IIIC. In these domains, foliations are defined by parallel, roughly planar alignments of flattened enclaves, large hornblende prisms and tabular plagioclase phenocrysts. In addition, in the western part of domain IIIC, spiralling orientations of hornblende prisms in cylindrical cells with radii of $2-5 \mathrm{~m}$ are present in quarries and 10-20 m diameter circular patterns of hornblende prisms are present in rock pavements. All orientations probably represent localized flow directions in the solidifying, crystal-poor magma since the smaller hornblende and plagioclase crystals, together with quartz, $\mathrm{K}$-feldspar and biotite crystals are not aligned, as would be expected if the body was intruded as a crystal-charged suspension, or if strong solid state flattening has occurred after solidification. The strain-direction markers indicate a sub-vertical northwestwards flow, while the circular patterns suggest that convection was locally vigorous. which might have favoured magma mixing.

\section{GEOCHRONOLOGY AND STRONTIUM ISOTOPE GEOCHEMISTRY}

An unexpectedly old age of $\sim 840 \mathrm{Ma}$ was obtained for the pluton by Santos et al. (1988) who used the Rb-Sr whole rock isochron method. Younger model Rb-Sr whole rock ages of $\sim 650 \mathrm{Ma}$ were reported for this granite type by Brito Neves and Cordani (1973) while Davison, and Santos (1989) obtained an age of $600 \pm 23 \mathrm{Ma}$ from a five-point isochron for a different post-tectonic granite in the Poço Redondo gneiss-migmatite domain.

The study undertaken by Chaves (1991) revealed gross Sr-isotopic heterogeneitics which determine the grouping of the samples in the discussion of the chemical compositions. Eleven new whole rock $\mathrm{Rb}-\mathrm{Sr}$ analyses, including four whole rock/enclave pairs, one other enclave and an aplite were used, together with the seven whole rock analyses previously reported by Santos et al. (1988) (Table 2). Age and $\mathrm{I}_{\mathrm{Sr}(\mathrm{t})}$ values quoted in the text are $2 \sigma$ values. Analytical details are given in the appendix. The aplite sample was initially excluded from the interpretation due to the large compositional gap which separates it from the other rocks.

A five-point isochron using enclaves only (Fig. 4, no. 1) yields an imprecise age of $\sim 762 \mathrm{Ma}$, while an eleven point isochron using granodiorites only yields an age of $\sim 879$ Ma (Fig. 4 no. 2). Conventional isochron treatment of the two populations together yields an age of $690 \pm 98 \mathrm{Ma}$ with widely scattered points (Fig. 4 no. 3).

The alternative isochron presentation proposed by Provost (1990) reveals two obvious groupings (Fig. 5), which correspond to a less radiogenic group with an age of $614 \pm 18 \mathrm{Ma}$ and $\mathrm{I}_{\mathrm{Sr}(614)}=0.70814 \pm 18$, and a more radiogenic group with a statistically identical age of $619 \pm 42 \mathrm{Ma}$ and $\mathrm{I}_{\mathrm{Sr}(619)}=0.71008 \pm 52$. The isotopic compositions of the two groups are statistically different, and the isotopic variation within both groups is probably significant. The aplite could be grouped with the less radiogenic population.

Table 2. Rb-Sr results for rocks from the CJS pluton

\begin{tabular}{|c|c|c|c|c|c|c|c|c|c|c|}
\hline Amostra & $\mathrm{Rb} p \mathrm{pm}$ & Sr ppm & $\mathrm{Rb} / \mathrm{Sr}$ & ${ }^{87} \mathrm{Rb} /{ }^{86} \mathrm{Sr}$ & 1 & ${ }^{87} \mathrm{Sr} r^{86} \mathrm{Sr}$ & 1 & $1 /^{86} \mathrm{Sr}$ & $\mathrm{I}_{\mathrm{Sr}(614)}$ & 1 \\
\hline CJS3 (a) & 47.0 & 740.0 & 0.06 & 0.184 & 0.005 & 0.70977 & 0.00009 & 1.201 & 0.70816 & 0.00010 \\
\hline CJS5 (a) & 710 & 736.0 & 0.10 & 0.281 & 0.008 & 0.71045 & 0.00005 & 1.207 & 0.70799 & 0.00009 \\
\hline $\operatorname{CJS} 9$ (a) & 77.0 & 687.0 & 0.11 & 0.327 & 0.009 & 0.71115 & 0.00006 & 1.294 & 0.70828 & 0.00011 \\
\hline CJSO42A (2) & 107.7 & 652.5 & 0.17 & 0.478 & 0.004 & 0.71235 & 0.00014 & 1.362 & 0.70816 & 0.00015 \\
\hline CJS036A (11) & 109.6 & 651.0 & 0.17 & 0.486 & 0.004 & 0.71243 & 0.00016 & 1.365 & 0.70815 & 0.00017 \\
\hline CJS044A (8) & 113.8 & 637.5 & 0.18 & 0.517 & 0.005 & 0.71300 & 0.00016 & 1.394 & 0.70847 & 0.00018 \\
\hline $\operatorname{CJS} 13$ (a) & 114.0 & 539.0 & 0.21 & 0.613 & 0.017 & 0.71563 & 0.00025 & 1.671 & 0.70995 & 0.00030 \\
\hline CJS2 (a) & 81.0 & 532.0 & 0.15 & 0.439 & 0.012 & 0.71380 & 0.00006 & 1.650 & 0.71035 & 0.00013 \\
\hline CJS036B (10) & 132.3 & 482.7 & 0.27 & 0.793 & 0.007 & 0.71506 & 0.00009 & 1.842 & 0.70811 & 0.00015 \\
\hline CJS017A (15) & 125.3 & 484.2 & 0.27 & 0.782 & 0.007 & 0.71726 & 0.00009 & 1.916 & 0.71040 & 0.00015 \\
\hline CJSO3IA (17) & 111.8 & 430.1 & 0.24 & 0.704 & 0.011 & 0.71614 & 0.00007 & 1.932 & 0.70997 & 0.00015 \\
\hline CJS044B (7) & 189.1 & 438.1 & 0.43 & 1.250 & 0.012 & 0.71940 & 0.00017 & 2.030 & 0.70844 & 0.00026 \\
\hline $\operatorname{CJS} 14$ (a) & 153.0 & 414.0 & 0.37 & 1.071 & 0.030 & 0.71951 & 0.00034 & 2.148 & 0.71012 & 0.00045 \\
\hline CJS4 (a) & 117.0 & 404.0 & 0.29 & 0.843 & 0.024 & 0.71543 & 0.00005 & 2.201 & 0.70804 & 0.00024 \\
\hline CJS10B (4) & 115.7 & 397.3 & 0.39 & 1.135 & 0.011 & 0.71803 & 0.00003 & 2.239 & 0.70807 & 0.00018 \\
\hline CJS042B (1) & 130.2 & 390.4 & 0.33 & 0.966 & 0.016 & 0.71633 & 0.00013 & 2.278 & 0.70785 & 0.00023 \\
\hline CJS017B (14) & 179.6 & 326.0 & 0.55 & 1.596 & 0.016 & 0.72401 & 0.00011 & 2.729 & 0.71001 & 0.00027 \\
\hline CJS031C (19) & 182.0 & 60.7 & 3.00 & 8.743 & 0.153 & 0.785456 & 0.00022 & 14.751 & 0.70787 & 0.00137 \\
\hline
\end{tabular}

$\mathrm{I}_{\mathrm{Sr}(614)}$, see text. (a) results reported by Santos et al. (1988).

Other numbers refer to analysed samples in Table 2 


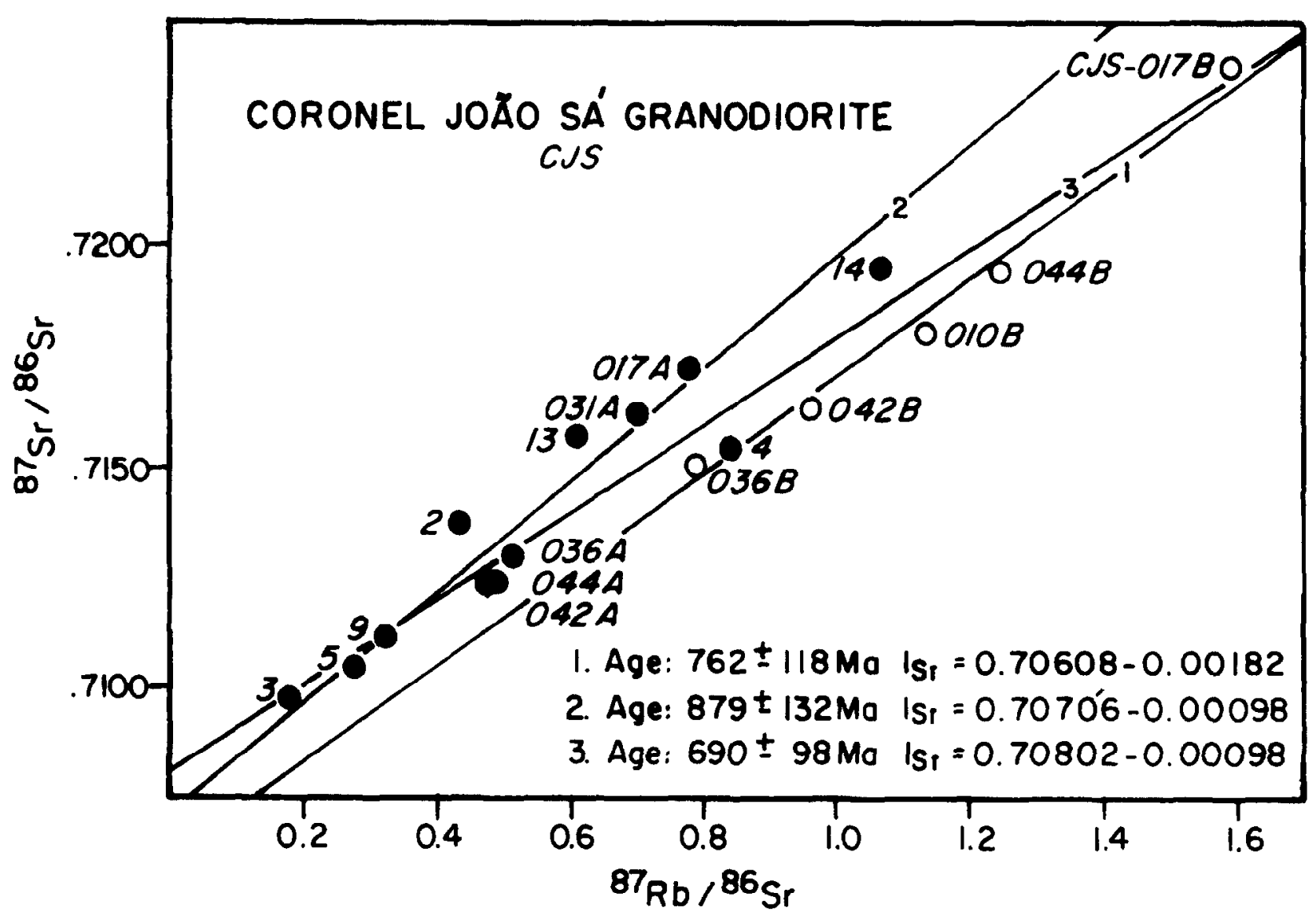

Fig. 4. Conventional isochron representations of data for enclaves only (open circles, no. 1), for granodiorites only (full circles, no. 2), and for all samples less aplite CJS $31 \mathrm{C}$ (no. 3).

We make the assumption that the analysed samples represent the isotopic composition of petrographical domains within the pluton, which can thus be divided into petrographic-isotopic domains. Granodiorites (HRG) and enclaves (HRE) with more radiogenic Sr compose the northern satellite body (domain IIIN) and the southern part (domain IS) of the eastern extremity. Less radiogenic granodiorites (LRG) and enclaves (LRE) compose most of the rest of the main body. No isotopic data are available for domain IIIW. A model intrusion age of $614 \mathrm{Ma}$, weighted in favour of the more precise isochron age, was adopted, and $\mathrm{I}_{\mathrm{Sr}(614)}$ values were calculated for all samples (Table 1).

With one exception, the enclaves have $\mathrm{I}_{\mathrm{Sr}(614)}$ values which are practically identical to those of the host rocks. This is probably a result of equilibration between enclaves and host rocks which occurs rapidly (Baker, 1989), is commonly observed (Fourcade and Javoy, 1991) and does not imply that the more mafic magmas contained more radiogenic $\mathrm{Sr}$.

\section{GEOCHEMISTRY}

Six enclave-host rocks pairs and one aplite were analysed in this study. The enclave powder samples were usually prepared from cut slabs or pieces corresponding to $25-50 \%$ of the total volume of each sample, and included the bioitite-rich rims. The accompanying granodiorite samples are from points between $20 \mathrm{~cm}$ and $5 \mathrm{~m}$ from the corresponding enclaves. Analytical methods are listed in the Appendix. Sixteen whole rock analyses including some trace elements are already available for the host granodiorites (Santos et al., 1988; Fujimori, 1989). All major element analyses were used to calculate mean compositions for some of the isotopic-petrographic types (Table 3 ). The $1 \sigma$ values reported include an unknown but probably small contribution from laboratory error. LRG samples include examples both associated and not associated with enclave swarms, while HRG and IIIW samples include examples with rare dispersed enclaves nearby as well as examples with no associated enclaves. The diorite sample CPRM 9 (Table 3, no. 9) from domain IIICp is important, since it may represent an intermediate hybrid formed by magma mixing.

Results reported by Fujimori (1989) for Rb concentrations are often discordant with those obtained by us and by Santos et al. (1988) for closely neighbouring sample points, often on the same outcrop. Fujimori's Rb results were not used in the compilation of Table 4.

The enclaves have compositions spanning the range from (monzo) gabbro to granodiorite. The major element compositions of the intermediate HRE (Table 3, no. 14) and LREs (nos. 1 and 10) are practically identical. In spite of the rareness of the Fe-Ti minerals, the rocks have rather constant $\mathrm{FeO}_{(\mathrm{t})} / \mathrm{MgO}$ ratios typical of calc-alkaline suites, while an iron-enrichment trend would be expected, 


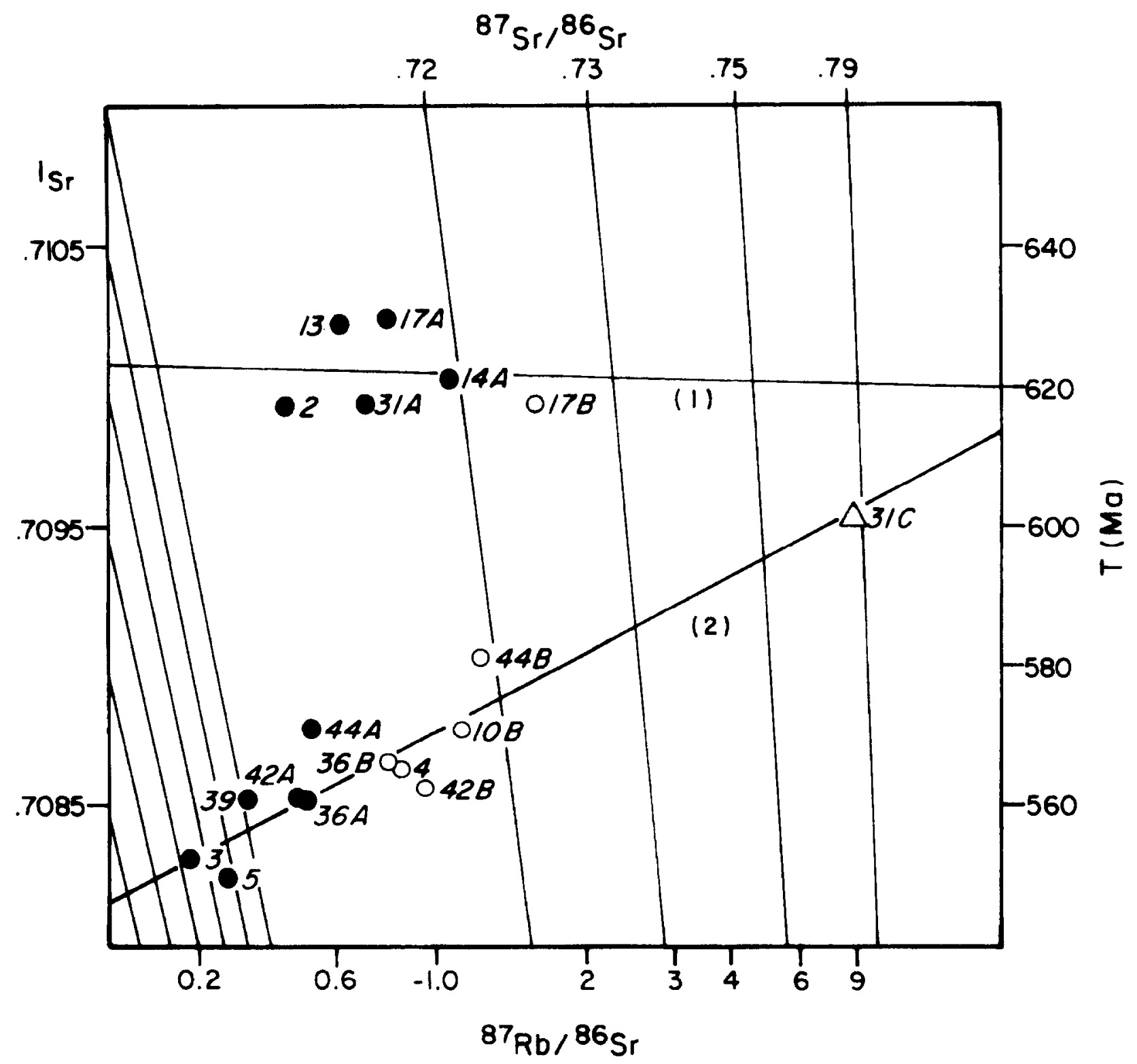

Fig. 5. Alternative isochron representation (Provost, 1990). Open triangle, aplite; other symbols as in Fig. 4.

especially for LRE (Fig. 6). The trend between the mafic and felsic compositional poles in the $R_{1}-R_{2}$ diagram (de La Roche et al. 1980) is transversal to those of typical modern rock suites (Fig. 7). Although these trends could be related to mixing involving a transalkaline mafic magma and a calc-alkaline felsic magma, scatter of LRE compositions in Harker diagrams is often too great to allow definition of a trend. In some cases (e.g. $\mathrm{K}_{2} \mathrm{O}$ : Fig. 8) the probable trend does not pass through the diorite composition, while in others (e.g. $\mathrm{Al}_{2} \mathrm{O}_{3}$ ), the extrapolated LRE trend passes through the diorite composition, but does not intersect the LRG field.

Quantitative mass balance tests for both less and more radiogenic suites using the most mafic enclave compositions as estimates of the mafic end members, the compositions of the more felsic enclaves as the hybrids, and the average granodiorite compositions as the felsic end members, yield inconsistent results. The inconsistencies are especially strong between $\mathrm{K}_{2} \mathrm{O}$ and $\mathrm{Zr}$ on the one hand, and $\mathrm{TiO}_{2}, \mathrm{FeO}_{(\mathrm{t})}, \mathrm{MgO}, \mathrm{CaO}$ and $\mathrm{P}_{2} \mathrm{O}_{5}$ on the other hand. While the latter group gives consistent estimates for the mass fraction of the mafic component involved, the former give lower or impossible (mass fraction of mafic member $>1.0$ ) estimates.

The $\mathrm{SiO}_{2}$ gap between enclave and granodiorite compositions may be an artifact of sampling, since the nearby NSG pluton (Fig. 1) has a number of samples with $\mathrm{SiO}_{2} \sim 61 \%$ (Table 3).

Most enclaves have higher HFSE and equal or higher $\mathrm{K}_{2} \mathrm{O}$ and $\mathrm{Zr}$ contents than the host granodiorites (Fig. 9). Similar features have been reported for many enclave/ host rock pairs and are usually attributed to chemical exchanges between the two (Holden et al. 1991; van der Laan and Wyllie, 1993). Data on protoliths and products of hydrothermal biotite formation in ultramafic (Lindenmeyer, 1981) and mafic (Brewer and Atkin, 1989) rocks demonstrate that additions of $\mathrm{K}_{2} \mathrm{O}$ and $\mathrm{Zr}$ to the ultramafic and mafic rocks occur during this process. 


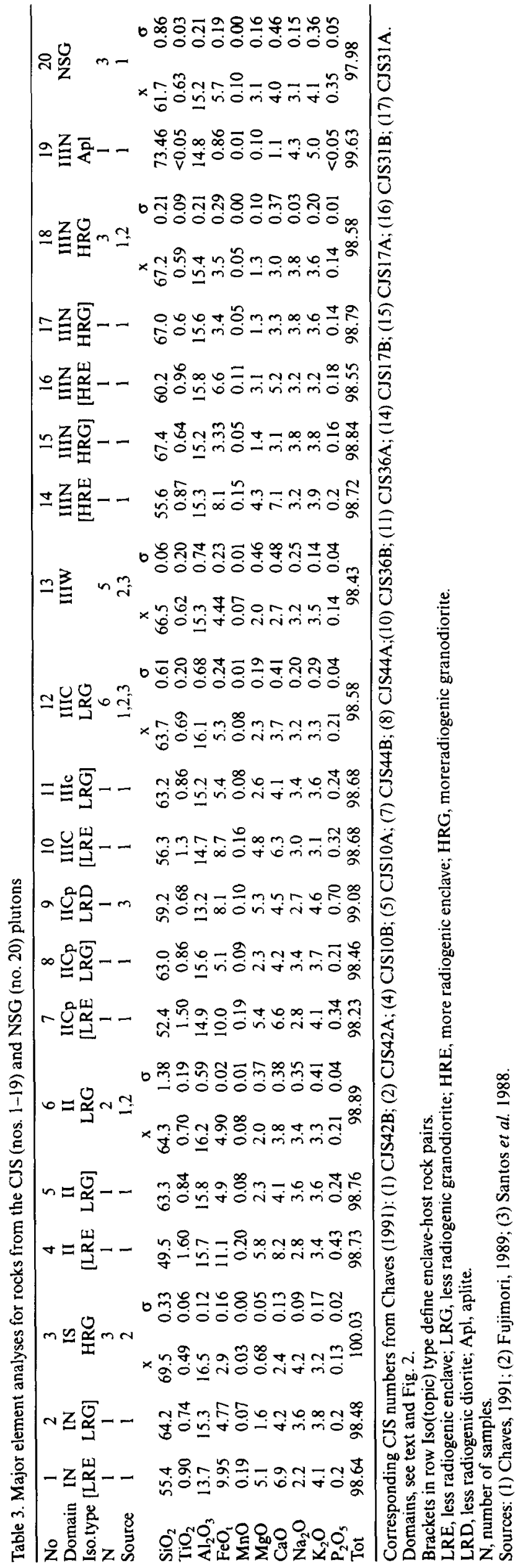


Table 4. Trace element analyses for selected samples; numbers as in Table 2

\begin{tabular}{lrrrrrrrrrrrrrrr}
\hline No & {$[1$} & $2]$ & {$[4$} & $5]$ & {$[7$} & $8]$ & 9 & {$[10$} & $11]$ & {$[14$} & $15]$ & {$[16$} & $17]$ & 19 & 20 \\
\hline $\mathrm{Rb}$ & 130 & 108 & 155 & - & 189 & 114 & 117 & 132 & 110 & 180 & 125 & - & 112 & 118 & 182 \\
$\mathrm{Sr}$ & 370 & 690 & 390 & 730 & 420 & 750 & 711 & 500 & 710 & 330 & 540 & 410 & 550 & 545 & 67 \\
$\mathrm{Ba}$ & 1140 & 1100 & 570 & 970 & 780 & 1210 & $\ldots$ & 800 & 1210 & 990 & 890 & 640 & 930 & 910 & 44 \\
$\mathrm{Y}$ & 14 & 30 & 40 & 29 & 29 & 27 & $\ldots$ & 48 & 34 & 25 & 14 & 28 & 24 & 17 & $<10$ \\
$\mathrm{Zr}$ & 280 & 310 & 440 & 430 & 380 & 330 & 647 & 390 & 400 & 330 & 310 & 360 & 330 & 320 & 20 \\
$\mathrm{Nb}$ & $<20$ & 24 & 30 & 30 & 26 & 24 & 32 & 34 & 28 & 26 & 360 & 30 & 20 & $<20$ & $<20$ \\
\hline
\end{tabular}

Multi-element N-MORB normalized (Pearce, 1982) patterns of the enclaves (Fig. 10) are similar to those of the enriched mafic rocks of the Gentileza volcanic unit of the Canindé complex (Fig. 1; Oliveira and Tarney, 1990). Giuliani and Santos (1988); Santos et al. (1988) presented rare earth element (REE) analyses for one diorite and two granodiorites from the CJS pluton. Chondrite-normalized patterns are light $\mathrm{REE}$-enriched with $\mathrm{La}_{\mathrm{N}} \sim 200$ and $\mathrm{Lu}_{\mathrm{N}} \sim 10$. Negative Eu anomalies are absent or insignificant. REE is higher in the diorite $(\sim 263 \mathrm{ppm})$ than in the granodiorites $(\sim 189$ and $\sim 195 \mathrm{ppm}$ ), probably as a consequence of accumulation of titanite and especially apatite in the diorite. Giuliani and Santos (1988) called attention to the similarities between the CJS REE patterns

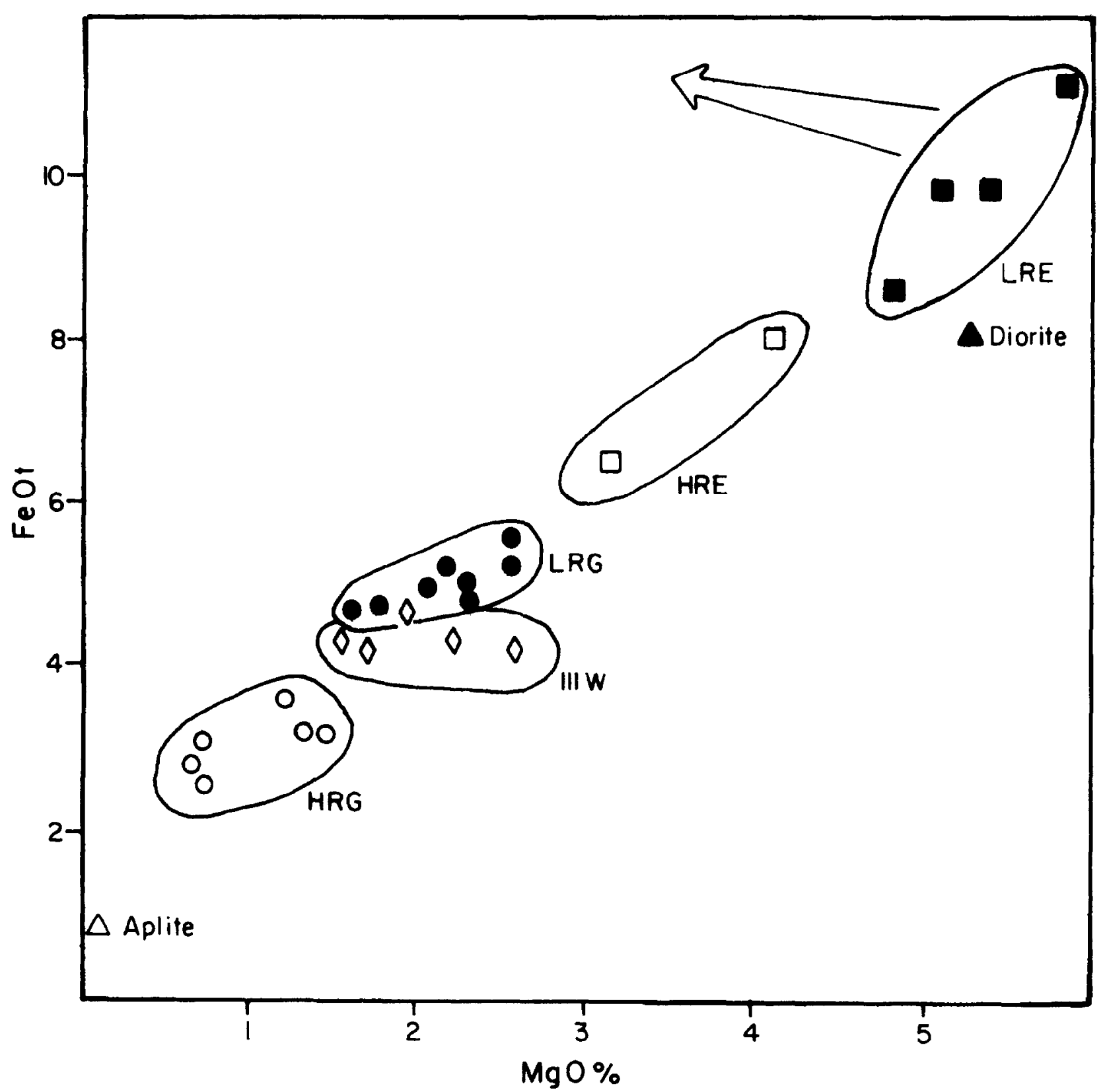

Fig. 6. $\mathrm{MgO}$ vs. $\mathrm{FeO}_{\mathrm{t}}$. Symbols: Full squares, LRE; open squares, HRE; full circles, LRG; open circles, HRG; open diamonds, domain IIIW; open triangle, aplite; full triangle, diorite. Arrow shows expected early tholeiitic differentiation trend (see text). 


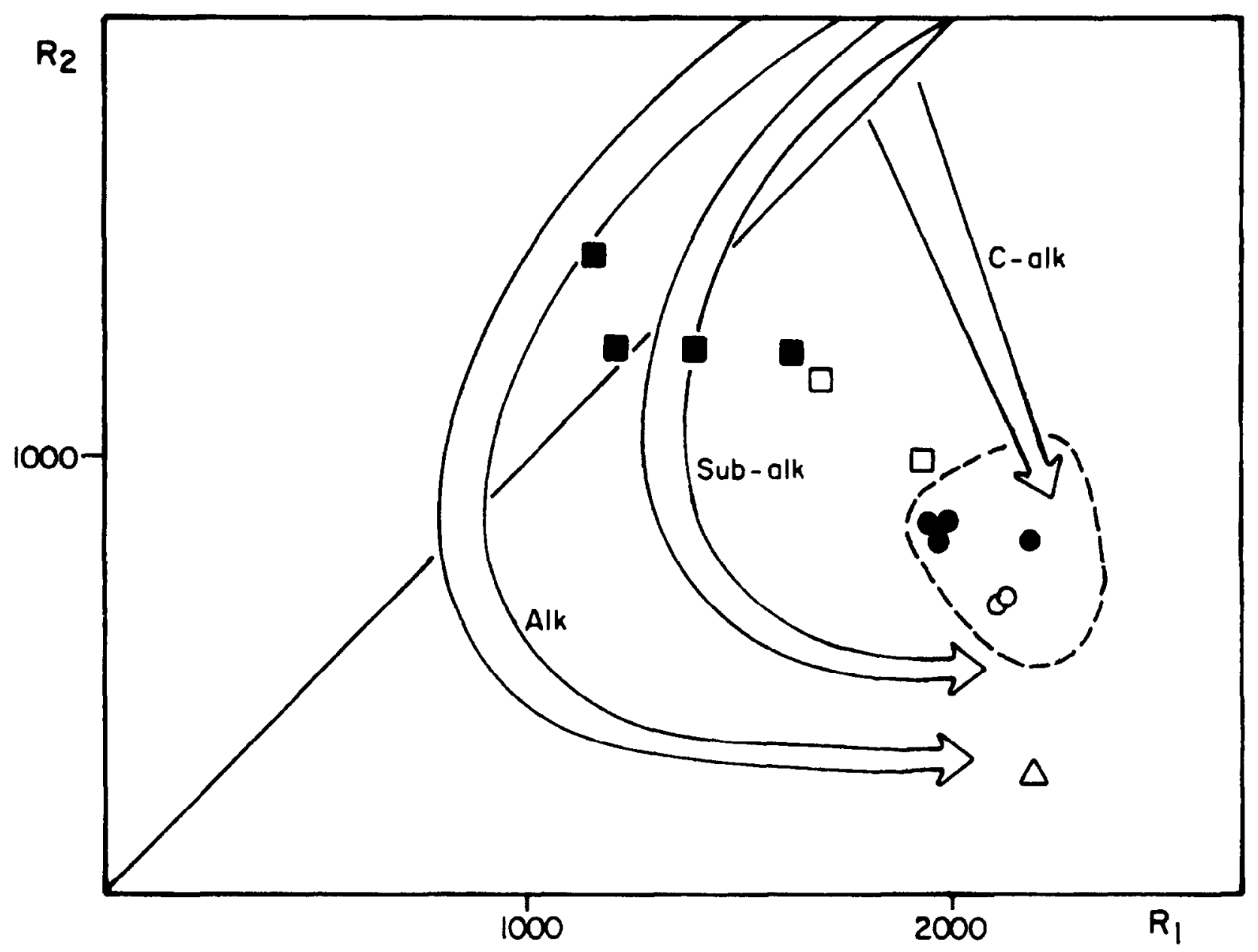

Fig. 7. R1 - R2 diagram of de La Roche et al. (1980). Symbols as in Fig. 6.

and those of K-rich calc-alkaline magmas. Apart from this, the REE pattern of the CJS diorite is very similar to that of an intermediate rock of the Gentileza volcanic unit (Oliveira and Tarney, 1990). The more felsic granodiorites have steep multi-element patterns (Fig.11) typical of collistonal granites (Pearce et al. 1984).

\section{The domains of the CJS pluton}

In all parts of the CJS pluton, a mafic-intermediate component was present. The less-radiogenic central part of the main body has a globally more mafic composition than the rest of the body, and also contains a larger proportion of mafic enclaves. In the main body, the more radiogenic rocks are limited to part of the eastern extremity of the intrusion which on structural grounds was the earliest phase of the intrusion. These rocks and their few accompanying enclaves are more felsic than other parts of the main body. The larger mass of more radiogenic rocks is found in the satellite body. Granodiorites in all domains except IIICp individually have rather homogeneous mineral and chemical compositions.

\section{DISCUSSION}

\section{The apparent age of the CJS pluton}

Since the enclaves have usually become isotopically equilibrated with their host rocks, their Rb-Sr composi- tions can be used in the construction of an isochron. This situation is different from previously reported cases (e.g. Macedo et al., 1993), in which artificially old apparent ages were obtained when results for large bodies of low $\mathbf{l}_{\mathrm{sr}}$ diorites were included in the isochron. The old apparent age obtained for the CJS pluton by Santos et al. (1988) results from the use of samples from two different Sr-isotopic groups.

Hybridization was involved both in the formation of the enclaves and in the genesis of the granodiorites, which acquired some crystals formed in a mafic magma. It is therefore possible that the apparent intrusion age is an artifact of the mixing process. Brasiliano-age granitoids are very abundant in the Borborema Province of Northeast Brazil (Sial, 1987). Available radiometric ages show that granite intrusions with $\sim 630 \mathrm{Ma}$ ages were strongly affected by tectonic activity on shear zones, while those with $<600 \mathrm{Ma}$ ages were only weakly deformed (Galindo et al. 1995). Since exact synchronism of events within the Borborema Province and the Sergipana belt is not expected, the $614 \mathrm{Ma}$ apparent age of the latetectonic CJS pluton is geologically plausible, but will need confirmation by other methods.

\section{Petrogenesis of the pluton}

The presence of LILE- and HFSE-enriched mafic magmas in other older parts of the fold belt (Oliveira 

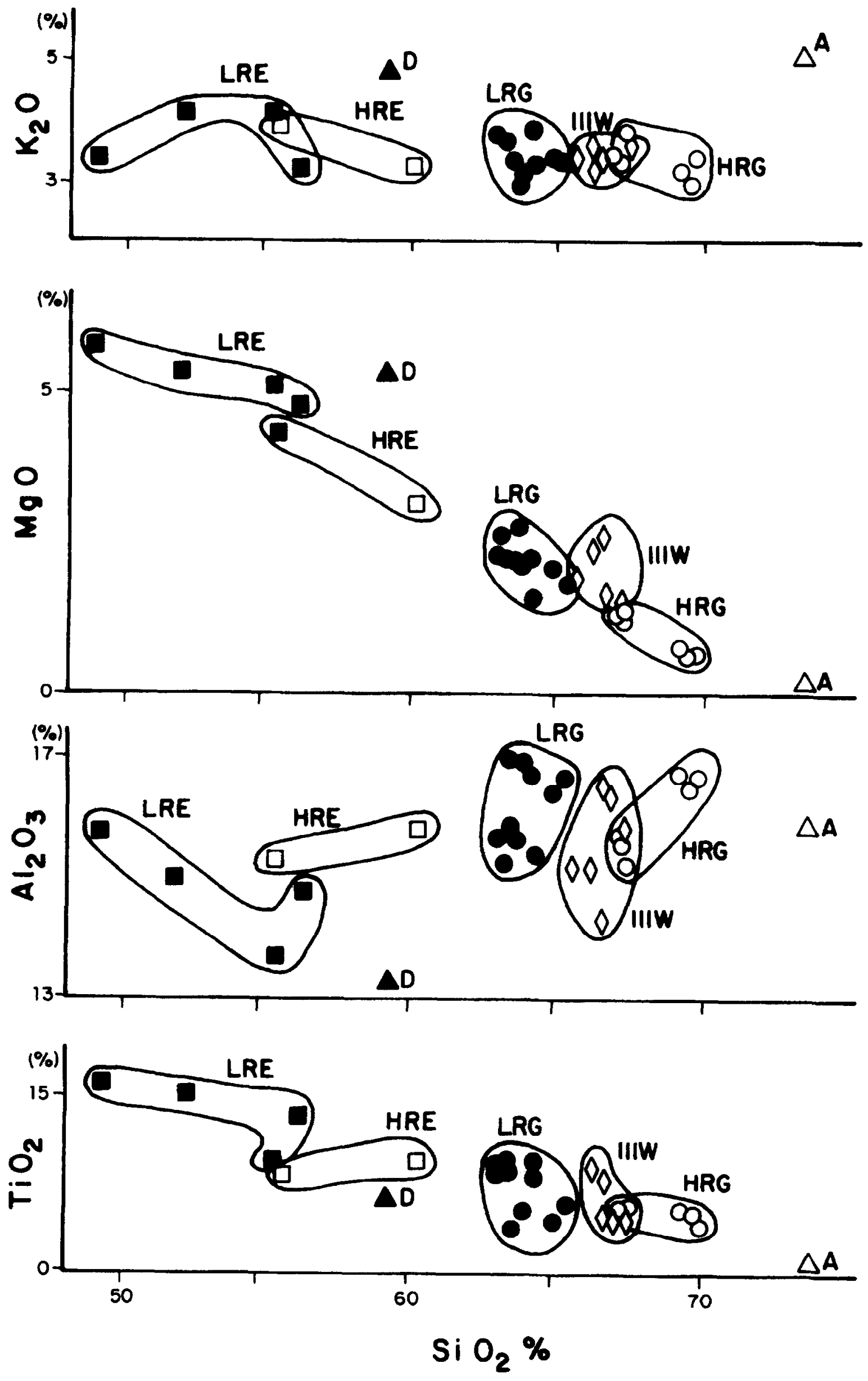

Fig. 8. Selected Harker variation diagrams. Symbols as in Fig. 6 


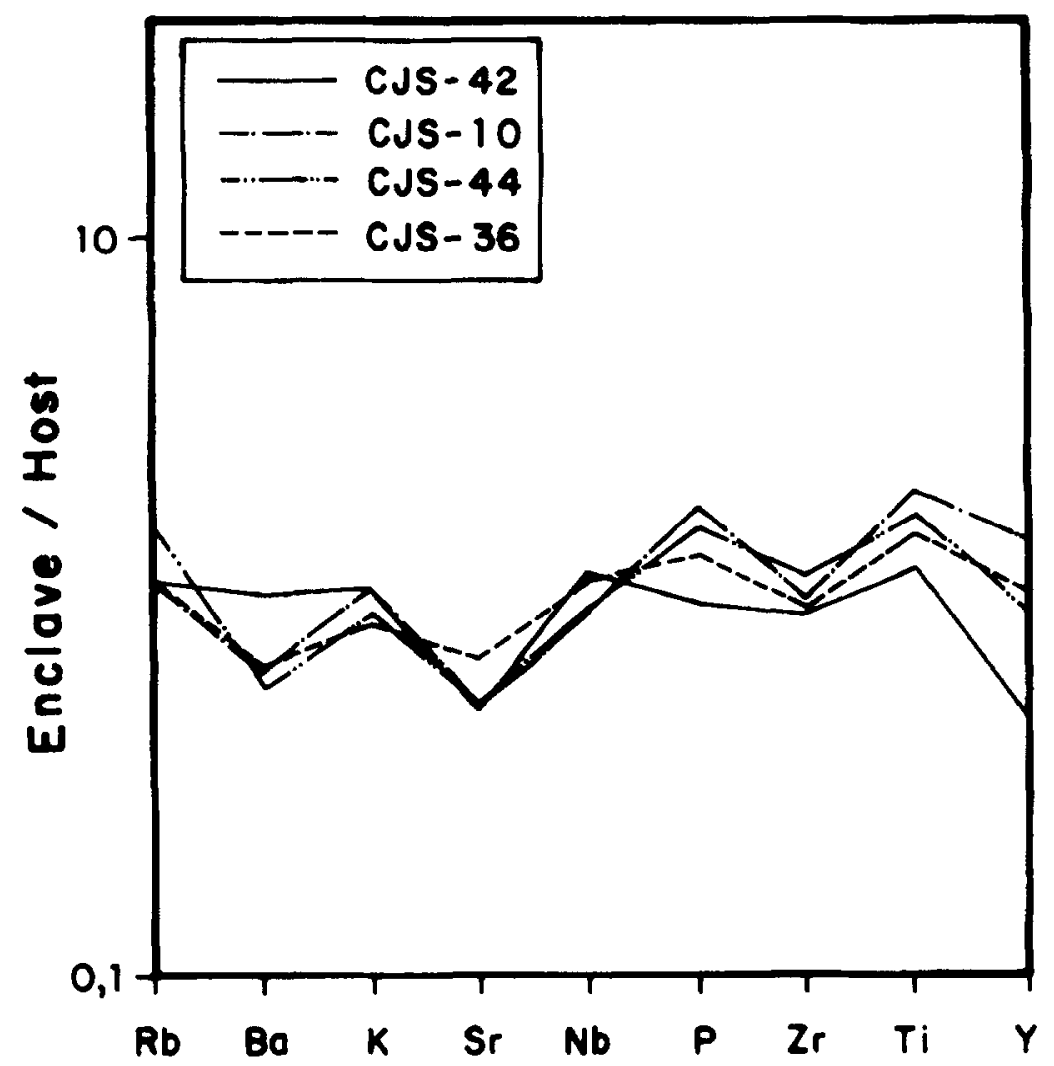

Fig. 9. Enclave/host rock element concentration ratios.

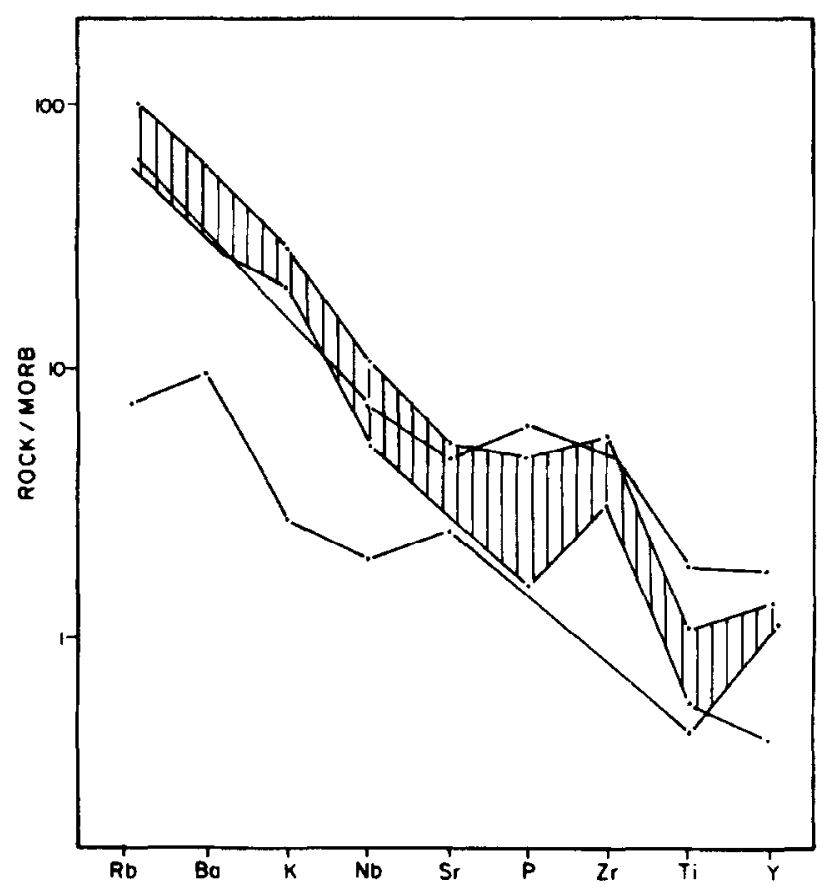

Fig. 10. MOR B-normalized (Pearce, 1982) multi-element variation diagrams showing envelope defining the range of mafic enclave compositions (cross-hatched), compared to the envelope of compositions of the mafic Gentileza volcanics of the Canindé igneous complex (Oliveira and Tarney, 1990)

and Tarney, 1990) leaves open the possibility that a similar mafic magma was also present later on during the formation of the CJS pluton. Textural evidence from the enclaves and host rocks shows that magma mixing between mafic and felsic magmas occurred at some depth below

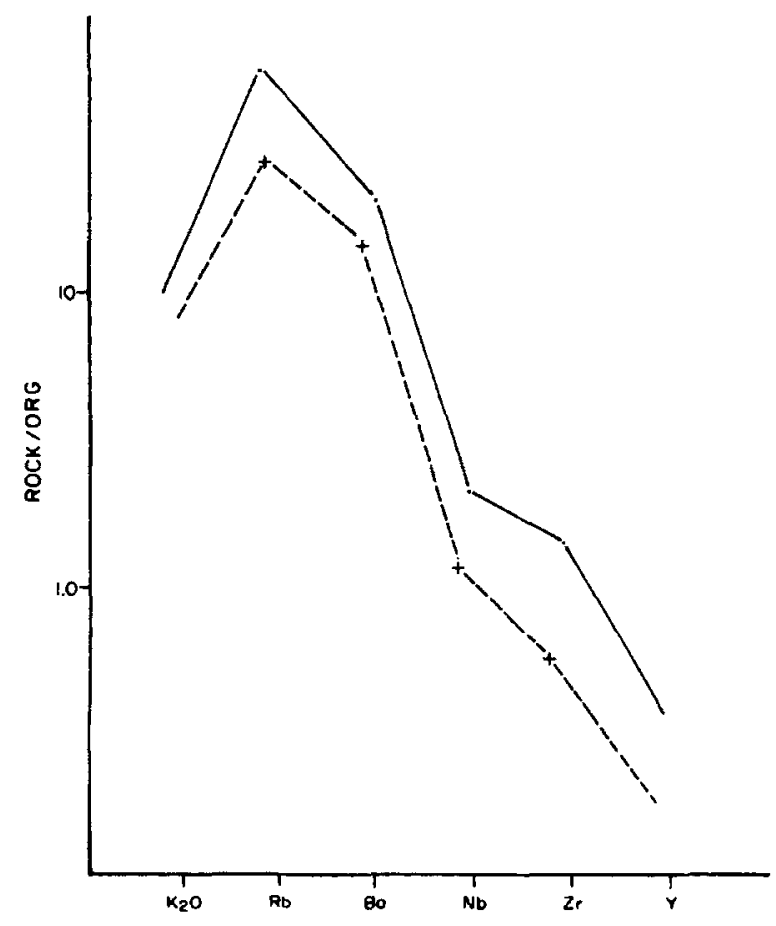

Fig. 11. Envelope of ORG-normalized (Pearce et al. 1984) multi-element variation patterns for more siliceous granodiorites.

the present exposure level during ascent from at least $18 \mathrm{~km}$. The division of the body into a number of petrographical-geochemical-isotopic domains suggests that the pluton had a complex feeder system. The fact that each domain contains different enclaves and host rocks suggests that no universal hybrid magma was 


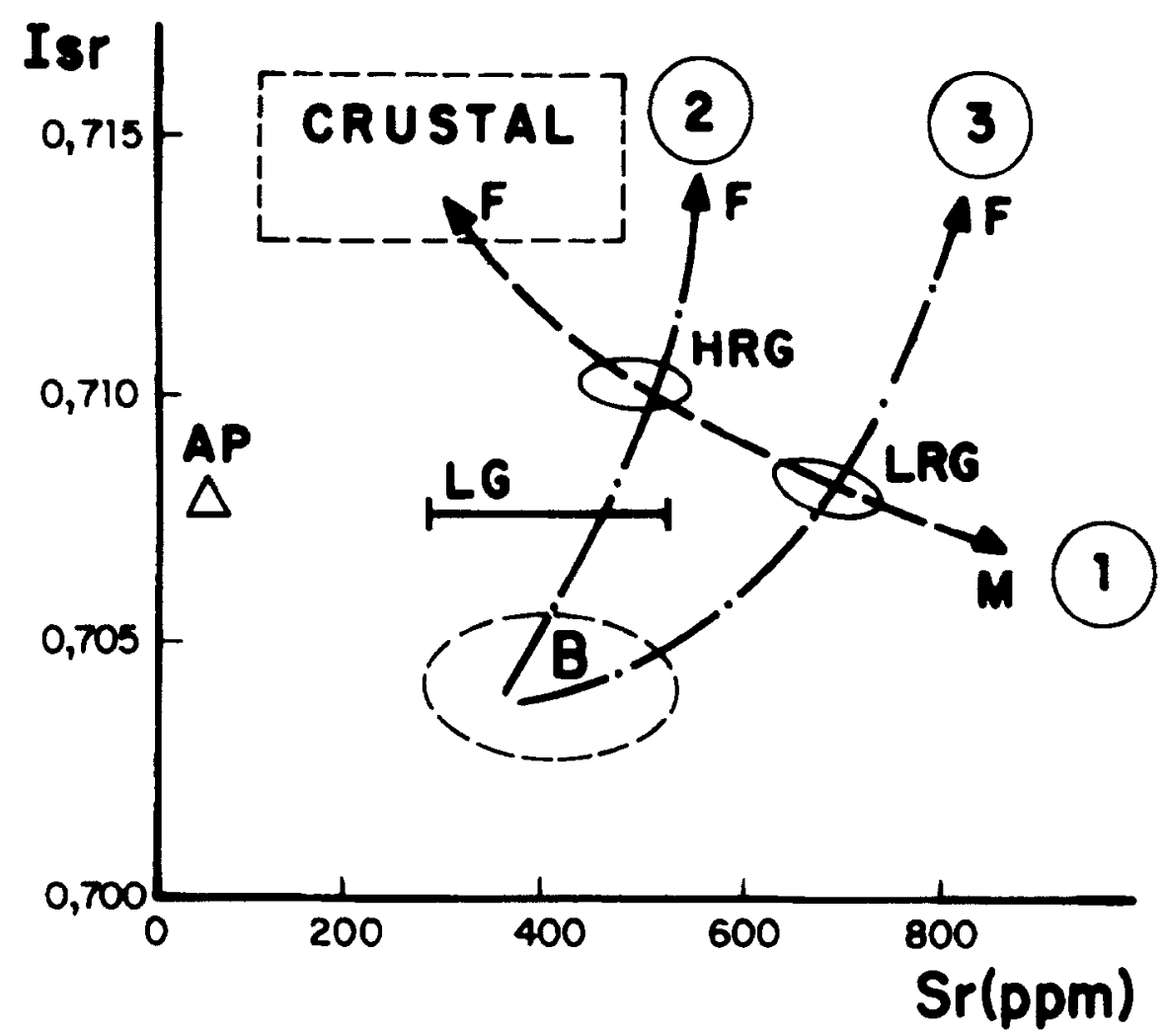

Fig. 12. Sr vs $\mathbf{I}_{\mathbf{S r ( 6 1 4 )}}$ values, showing ellipsoid areas corresponding to CJS LRG and HRG; open triangle, CJS aplite; LG bar, composition of Poço Redondo leucogranite (Davison and Santos, 1989); B, possible field of basalts; Crustal Field uses notional

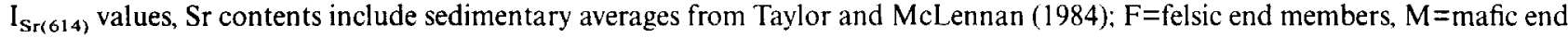
member. Paths 1,2 and 3 , see text.

present, and the magmas which fed each domain may have undergone different evolutions.

Nevertheless, the mineral, elemental and Sr-isotopic compositions in all domains except IIICp are individually relatively homogeneous, and the host granodiorites may therefore represent relatively well-mixed end products. The association of more mafic enclaves with more mafic host rocks in the centre of the body, and of more felsic enclaves and host rocks in the remainder of the body suggests that the proportions of mafic and felsic magmas could have been different in the different parts of the feeder system. Structural evidence in some parts of the body points to the action of vigorous convection in relatively crystal-poor granodiorite magmas, which would favour mixing.

It is unlikely that enriched mantle-derived magmas would have $\mathrm{I}_{\mathrm{Sr}(614)}$ very much higher (e.g. 0.7080) than the bulk earth linear evolution model at that time ( $\sim 0.7038$ ), although they could have Sr contents overlapping with those of the mafic enclaves. If $L R G$ and $H R G$ were formed by magma mixing between single mafic and felsic end-members, the mafic magma would require a very high Sr content (Fig. 12 no. 1), and no such magma has so far been encountered in the Sergipana belt. For example, the Gentileza mafic volcanics have $\mathrm{Sr}=\sim 310$ $\sim 490 \mathrm{ppm}$ (Oliveira and Tarney, 1990). If the mafic member had a "normal" Sr content, then LRG and HRG must be products of magma mixing with different $\mathrm{Sr}$-rich felsic end members (Fig 12 nos. 2 and 3). High Sr contents of around $1000 \mathrm{ppm}$ have been recorded in post-tectonic syenites in the Sergipana belt (Santos and Souza, 1988).

A Brasiliano-age leucogranite from the Poço Redondo migmatitic domain has $\mathrm{I}_{\mathrm{Sr}(614)}=0.708$ (Davison and Santos, 1989), similar to that of the CJS aplite. The leucogranites in this domain are products of anatexis of tonalitic to granodioritic gneisses (Bezerra, 1992). Leucogranitic magmas of this type are not an adequate felsic end member for the CJS mixing process. More radiogenic $\mathrm{Sr}$ may be present in the continentally derived metapelites of the Macururé domain. Although no data are available on these metapelites, they are likely to be Rb-rich and are older than the CJS pluton.

\section{CONCLUSIONS}

The age of 614 Ma obtained by the Rb-Sr whole rock isochron method for the CJS pluton is geologically plausible, and provides a minimum age which is probably close to its intrusion age. While rocks of the eastern extremity of the pluton were deformed, the remainder of the intrusion has only magmatic orientations, and no solid-state deformation is present in the granite in the proximities of the São Miguel do Aleixo fault, which deformed the $\mathrm{S}_{2}$ foliation of the host Macururé schists. The age obtained is therefore a minimum for the $D_{2}$ deformation phase in the Macururé domain of the Sergipana fold belt.

The $\mathrm{Sr}$ isotopic compositions of most enclaves and 
host granodiorites reached equilibrium, and the enclaves can therefore be used in the isochron treatment. Textural evidence, especially from the enclaves, shows that magma mixing between mafic and felsic magmas occurred, but the chemical compositions of the enclaves were modified probably during late development of biotite and are therefore inadequate for geochemical tests of the mixing hypothesis.

Although the felsic rocks are texturally, mineralogically and chemically similar, their Sr-isotopic compositions are heterogeneous. The heterogeneity was probably caused by separate evolution of different magma batches in a feeder system which passes through different basement or supracrustal lithologies.

Acknowledgements - Part of this work was presented in Chave's MSc Thesis, and was supported by a National Research Council (CNPq) research grant to Davison, and by the project "Granitoids of Bahia State", coordinated by P. Sabaté and supported by the Financing Agency for Studies and Projects (FINEP/PADCT). McReath acknowledges a CNPq Research Scholarship. We thank I. Guimarães and A. Silva Filho for discussions and access to their thin section collection, and to A.N. Sial for discussions on the enclaves and their origins. J. Baker provided a rigorous review of an early version, which contributed substantially to the improvement of the text. A.N. Sial, R. Sacchi and R. Fuck are also thanked for their comments.

\section{REFERENCES}

Almeida, F.F.M. de, Hasui, Y., Brito Neves, B.B. de and Fuck, R.A. (1981). Brazilian structural provinces: an introduction. Earth Science Reviews, 17, 1-130.

Baker, D.R. (1989). Tracer versus trace element diffusion: Diffusion decoupling of $\mathrm{Sr}$ concentration from $\mathrm{Sr}$ isotopic composition. Geochimica et Cosmochimica Acta, 53, 3015-3023.

Bezerra, F.H.R. (1992). Geologia e evolução petrológica do complexo gabróico Canindé do São Francisco e rochas adjacentes (Sergipe e Alagoas). Unpublished Master's Thesis, Universidade de Brasilia. $208 \mathrm{p}$.

Brewer, T.S. and Atkin, B.P. (1989). Element mobilities produced by low-grade metamorphic events, a case study from the Proterozoic supracrustals of Southern Norway. Precambrian Research, 45, 143-158.

Brito Neves, B.B. de and Cordani, U.G. (1973). Problemas geocronológicos do "Geosinclinal Sergipano" e seu embasamento. XXVII Congresso Brasileiro de Geologia, Aracajú, Brazil. Anais, 2, 67-76.

Campos Neto, M.C. and Brito Neves, B.B. de (1987). Considerações sobre a organização e geometria do Sistema de Dobramentos Sergipanos. Primeiro Simpósio Nacional de Estudos Tectônicos. Salvador, Brazil. Bol. Resumos, 90-93 (Abstract).

Chaves, J.M. (1991). Maciços Cel. João Sá e Glória: Petrologia e geoquimica de granitóides do Dominio Macururé, Faixa Sergipana ( $N E$ do Brasil). Unpublished Master's Thesis, Universidade Federal da Bahia. 153 p.

Davison, I. and Santos, R.A. dos (1989). Tectonic evolution of the Sergipano Fold Belt, NE Brazil, during the Brasiliano Orogeny. Precambrian Research, 45, 319-342.

Didier, J. and Barbarin, B. (1991). The different types of enclaves in granites - Nomenclature. In J. Didier and B. Barbarin (Eds.), Enclaves and granite petrology (pp. 293-312). Amsterdam: Elsevier.
Fourcade, S. and Javoy, M. (1991). Sm-Nd-O isotopic features of mafic microgranular enclaves and host granitoids from the Pyrenees, France: evidence for their hybrid nature and inference on their origin. In J. Didier and B. Barbarin (Eds.), Enclaves and granite petrology (pp. 345-364). Amsterdam: Elsevier.

Fujimori, S. (1989). Contribuição ao estudo dos granitóides do sistema de dobramentos Sergipano. Revista Brasileira de Geociências, 19, 241-247.

Galindo, A.C., Dall'Agnol, R., McReath, I, Lafon, J.M. and Teixeira, N.P. (1995). Evolution of Brailiano-age granitoid types in a shearzone environment, Umarizal-Caraúbas region, Rio Grande do Norte, northeast Brazil. Journal of South American Earth Sciences, $8,79-95$.

Giuliani, G. and Santos, R.A. dos (1988). Geoquimica de alguns granitóides da Faixa de dobramentos Sergipana. $X X X V$ Congresso Brasileiro de Geologia, Belém, Brazil. Anais, 4, 1037-1052.

Guimarães, I. de P. and Silva Filho, A.F. da (1993). Significado dos enclaves máficos do complexo Coronel João Sá, Faixa Sergipana, BA. XV Simpósio de Geologia do Nordeste, Natal, Brasil. Boletim, 13,93-94 (abstract).

Guimarães, I. de P. and Silva Filho, A. F. da (1994). The potassic intrusive magmatism in the northern border of the Sergipano fold belt: shoshonitic affinity? 38 Congresso Brasileiro de Geologia, Cambiü, Brazil. Bol. Resumos Expandidos, 1, 211-212.

Hibbard, M.J. (1991). Textural anatomy of twelve magma-mixed granitoid systems. In J. Didier and B. Barbarin (Eds.), Enclaves and granite petrology (pp. 431-444). Amsterdam: Elsevier.

Holden, P., Halliday, A.N., Stephens, W.E. and Henney, P.J. (1991). Chemical and isotopic evidence for major mass transfer between mafic enclaves and magmas. Chemical Geology, 92, 135-152.

Hutton, D.H.W. (1988). Granite emplacement mechanisms and tectonic controls: inferences from deformation studies. Transactions of the Royal Society of Edinburgh (Earth Sciences), 79, 245-255.

Jardim de Sá, E.F., Moraes, J.A.C. and Silva, L.H.d'El R. (1986). Tectônica tangencial na Faixa Sergipana. $X X X I V$ Congresso Brasileiro de Geologia, Goiânia, Brazil. Anais, 3, 1246-1256.

Johnson, M.C. and Rutherford, M.J. (1989). Experimental calibration of the aluminum-in hornblende geobarometer with applications to Long Valley caldera (California) volcanic rocks. Geology, 17, 837-841.

de La Roche, H., Leterrier, J., Granclaude, P. and Marchal, M. (1980). A classification of volcanic and plutonic rocks using $R_{1}-R_{2}$ diagram and major element analyses; its relationship with current nomenclature. Chemical Geology, 29, 183-210.

Lindenmeyer, Z.G. (1981). Evolução geológica do vale do rio Curaçá e dos corpos máfico-ultramáficos mineralizados em cobre. In H.A.V. Inda, M.M. Marinho and F.B. Duarte (organizers) Geologia e recursos Minerais do Estado da Bahia: Textos Básicos 4 (pp. 72 110). CPM/SME-BA, Brazil: Salvador.

Macedo, M.H. de F, Jardim de Sá, E.F., Kawashita, K. and Araújo, M.A.T. de (1993). Errócronas, pseudo-isócronas e retas de mistura: Exemplos das suites de $\mathrm{K}$-dioritos brasilianos na Faixa Seridó. $X V$ Simpósio de Geologia do Nordeste, Natal, Brazil. Boletim no. 13 (resumos), 328-331 (abstract).

Mariano, G. and Sial, A.N. (1990). Coexistence and mixing of magmas in the late Precambrian Itaporanga batholith, State of Paraiba, northeastern Brazil. Revista Brasileira de Geociências, 20, 101-110.

Neves, S.P. and Vauchez, A. (1995). Successive mixing and mingling of magmas in a plutonic complex of Northeast Brazil. Lithos, 34, 275-299.

Oliveira, E.P. and Tarney, J. (1990). Petrogenesis of the Canindé de São Francisco Complex: A major Late Proterozoic gabbroic body in the Sergipe Foldbelt, Northeastern Brazil. Journal of South American Earth Sciences, 3, 125-140. 
Pearce, J.A. (1982). Trace element characteristics of lavas from destructive plate margins. In R.S. Thorpe (Ed.) Andesites (pp. 525-548). New York: Wiley.

Pearce, J.A., Harris, N.B.W. and Tindle, A.G. (1984). Trace element discrimination diagrams for the tectonic interpretation of granitic rocks. Journal of Petrology, 25, 956-983

Provost, A. (1990). An improved diagram for isochron data. Chemical Geology (Isotope Geoscience Section), 80, 85-99.

Santos, R.A. dos and Souza, J. D. de (1988). Programa Levantamentos Geológicos Básicos do Brasil. Piranhas: Folha SC.24-X-C-VI. Texto Explicativo. Brasília: DNPM/MME

Santos, R.A. dos, Menezes Filho, N.R de and Souza. J.D. de (1988). Programa Levantamentos Geológicos Básicos do Brasil. Carira: Folha SC.24-Z-A-III. Texto Explicativo. Brasília: DNPM/MME

Schmidt, M.W. (1992). Amphibole composition in tonalite as a function of pressure: an experimental calibration of the Al-in-hornblende barometer. Contributions to Mineralogy and Petrology, 110.304-310.

Sial, A.N. (1987). Granitic rocks of northeast Brazil. International Symposium on Granites and Associated Mineralizations. Brazil: Salvador. Extended Abstracts: 61-69.

Sial, A.N., Ferreira, V.P. and Mariano, G. (1992). Coexistence of two magmas and igneous processes in some Brasiliano age granitoids in northeastern Brazil. 37 Congresso Brasileiro de Geologia, São Paulo. Brazil. Boletim Resumos Expandidos, 1, 362 363 (abstract).

Silva Filho, A.F. and Guimarães, 1.P. (1994). Avaliação da pressão de cristalização dos principais corpos do Sistenla de Dubramentos Sergipano a partir de geobarometria de Al em hornblenda. 38 Congresso Brasileiro de Geologia, Cambiriú, Brazil. Boletim Resumos Expandidos, I, 211-212 (abstract).

Steiger. R.H. and Jäger, E. (1977). Subcommission on geochronology: convention for the use of decay constants in geo- and cosmochronology. Earth and Planetary Science Letters, 36, 359--362.

Streckeisen, A.L. (1976). To each plutonic rock its proper name. Earth Science Reviews, 12, 1-33.

Taylor, S.R. and McLennan, S.M. (1984). The Continental Crust: its composition and evolution. Oxford: Blackwell Scientific Publications. $312 \mathrm{p}$.

Williamson, J.H. (1968). Least squares fitting of a straight line. Canadian Journal of Physics, 46, 1845-1847.

van der Laan, S.R. and Wyllie, P.J. (1993). Experimental interaction of granitic and basaltic magmas and implications for mafic enclaves. Journal of Petrology, 34, 491-518.
Van Schmus, W.R., Brito Neves, B.B., Hackspacher, P., Babinski, M., Fetter, A. and Dantas, E. (1995). Neoproterozoic and late Mesoproterozoic sedimentary and volcanic sequences in the Borborema Province, NE Brazil. 16 Simpósio de Geologia do Nordeste, Recife, Brazil Boletim, 14(2), 391-393 (abstract).

Vernon. R.H. (1990). Crystallization and hybridism in microgranitoid enclave magmas: Microstructural evidence. Journal of Geophysical Research, 95(B11), 1784917859.

Vernon, R.H. (1991). Interpretation of microstructures of micrograniotoid enclaves. In J. Didier and B. Barbarin (Eds.), Enclaves and granite petrology. (pp. 277-291). Amsterdam: Elsevier.

Wyllie, P.J., Cox, K.G. and Biggar, G.M. (1962). The habit of apatite in synthetic systems and igneous rocks. Journal of Petrology, 3 , $238-243$.

York, D. (1966). Least-squares fitting of a straight line. Canadian Journal of Physics, 44, 1079-1086

York, D. (1990). Least-squares fitting of a straight line with correlated errors. Earth and Planetary Science Letters, 5, 320-324.

Zen, E.-A and Hammarstrom, J.M. (1984). Magmatic epidote and its petrologic significance. Geology, 12, 515-518.

\section{APPENDIX}

Chemical analyses for most elements were obtained from the commercial laboratory GEOLAB, Belo Horizonte, Brazil. The methods used included wet chemical and X-ray fluorescence methods. Quality checking used hidden international standards and replicates. New $\mathrm{Rb}$ and $\mathrm{Sr}$ determinations reported here were undertaken at the Isotope Geology Laboratory of the Geosciences Centre, Federal University of Pará (LGI/ CG/UFPA) by isotope dilution. Santos et al. (1988) also used GEOLAB services, while Fujimori (1989) obtained his results from the Centre for Research and Development (CEPED), Salvador, Brazil where similar combinations of analytical methods were used.

$\mathrm{Sr}$ isotopic compositions were obtained at the LGI/CG/UFPA. About $100 \mathrm{mg}$ whole rock powder was dissolved in concentrated $\mathrm{HF}$ and $\mathrm{HNO}_{3}+\mathrm{HClO}_{4}$ after addition of a mixed ${ }^{84} \mathrm{Sr}_{-}{ }^{87} \mathrm{Rb}$ spike. $\mathrm{Rb}$ and $\mathrm{Sr}$ extraction and purification was done using 200-400" AG Dowex 50X8 cationic exchange resin. The $\mathrm{Rb}$ and $\mathrm{Sr}$ extracts were separately loaded on single $W$ filaments, and isotopic determinations were performed on an ISOMASS VG54E single collector mass spectrometer. Corrections for mass discrimination were normalized to ${ }^{84} \mathrm{Sr} /{ }^{86} \mathrm{Sr}=0.1194$. Rb and $\mathrm{Sr}$ blanks were less than $5 \mathrm{ng}$. Isochron ages and initial $\mathrm{Sr}$ isotopic ratios were calculated using the modified York (1966, 1969); Williamson (1968) plocedures. The decay constant $1=1.42 \times 10^{~ " ~}$ (Steiger and Jäger, 1977) was used. Results reported by Santos et al. (1988) were obtained at the Geochronological Research Centre of the University of São Paulo (CPGeo/USP) using very similar procedures. 